\title{
Konsepsi dan Bentuk BUMDes dalam Peningkatan Kesejahteraan Masyarakat di Provinsi Jambi
}

\author{
Lili Naili Hidayah*, Muskibah, Ageng Triganda \\ Fakultas Hukum Universitas Jambi \\ *Correspondence email: lilinailihidayah@unja.ac.id, muskibah@yahoo.co.id, ageng.fh@unja.ac.id
}

\begin{abstract}
Abstrak. Artikel ini membahas tentang Konsep dan bentuk Badan Usaha milik Desa juga melihat bagaimana peranannya sebagai salah satu cara meningkatkan tingkat kesejahteraan masyarakat desa di Provinsi Jambi dan apa sajakah yang menjadi tantangan dan hambatan dalam pelaksanaannya. Kehadiran lembaga ini semestinya dapat dijadikan langkah yang tepat dalam upaya mewujudkan kesejahteraan masyarakat Desa terutama dalam bidang perekonomian dan dalam rangka membangun masyarakat desa, yang diharapkan dapat menekan angka kemiskinan. Ketentuan dalam UU Desa tentang aturan pelaksana yang menginginkan badan usaha haruslah mencerminkan desa yang memiliki sifat kekeluargaan dan gotong royong tersebut dan ditegaskan dalam UU Desa badan usaha yang dimiliki desa nantinya bisa berbadan hukum ataupun tidak badan hukum namun tidak bisa disamakan dengan badan hukum yang biasa dikenal dalam dunia usaha. Seperti CV, PT maupun koperasi. Dalam Pelaksanaan BUMdes sering kali masalah badan hukum dipertanyakan oleh pihak ketiga manakala akan bekerjasama, sehingga ada beberapa hambatan pelaksanaaan pengelolaan BUMdes.
\end{abstract}

Kata kunci: Konsepsi dan Bentuk BUMdes; Kesejahteraan; Tantangan dan Hambatan

\begin{abstract}
This article discusses the concept and form of village-owned enterprises and sees how it plays a role as a way to increase the level of welfare of rural communities in Jambi Province and what are the challenges and obstacles in its implementation. The presence of this institution should be the right step in an effort to realize the welfare of the Village community, especially in the economic sector and in the context of developing rural communities, which are expected to reduce poverty. The provisions in the Village Law regarding implementing rules that want a business entity to reflect a village that has kinship and mutual cooperation and is confirmed in the Village Law that business entities owned by the village can later be legal or not legal but cannot be equated with legal entities commonly known. in the business world. Such as CV, PT and cooperatives. In the implementation of BUMdes, the problem of legal entities is often questioned by a third party when working together, so there are several obstacles to implementing BUMdes management.
\end{abstract}

Keyword: Consept and Form; Welfare; Challenges and Barriers

\section{PENDAHULUAN}

Keadilan yang merata bukanlah sesuatu hal yang gampang untuk diwujudkan seperti yang telah dimandatkan konstitusi, dimana amanat tersebut merupakan harapan tertinggi bangsa kita, yaitu ingin mewujudkan masyarakat yang lebih sejahtera dimana keadilan serta kemakmuran merata diseluruh wilayahnya.

Perwujudan dari harapan bangsa yang tertinggi tersebut bukanlah pekerjaan yang mudah dan instan bisa dicapai dalam waktu singkat. Upaya demi upaya dilakukan secara terus menerus dan berkesinambungan. Dan dikarenakan butuh upaya dalam mewujudkan apa yang termaktub dalam konstitusi maka perlu usaha yang besar agar harapan terbesar dapat tercapai. Salah satunya adalah merencanakan pembangunan yang diorientasikan pada masyarakat dan melibatkannya dalam sebuah partisipasi pembangunan desa. Adanya partisipasi yang melibatkan masyarakat dalam pembangunan ini diharapkan dapat meningkatkan pendapatan desa dengan menyerap tenaga kerja sehingga tingkat pengangguran berkurang dan harapan terbesarnya dapat mewujudkan kesejahteraan masyarakat setempat ${ }^{1}$.

Selaras dengan itu Zulkarnain Ridlwan dalam Jurnal Fiat Justitia mengatakan bahwa desa diharapakan ikut berperan serta secara aktif dalam perwujudan cita citanegara dikatakan lebih lanjut bahwa peran tersebut salah satunya langkahnya yaitu dengan ikut mengupayakan peningkatan pendapatan asli desa atau yang biasa disebut PADes. Badan usaha dibentuk sebagai alat pendorong dan penggerak ekonomi yang berada dimasyarakat pedesaan. ${ }^{2}$

Badan usaha dibentuk dalam rangka meningkatkan dan menggerakkan perekonomian desa di sesuaikan dengan karakteristik desa seperti unsur geografis, sumber daya manusia yang dimiliki desa, sehingga badan usaha yang didirikan tentunya akan berbeda beda dari desa satu dengan desa lainnya.

Pemerintah berupaya penuh untuk mendorong kemandirian masyarakat pedesaan, agar desa ikut berpartisipasi membangun daerah dengan kemampuan dan sumberdaya yang mereka miliki. Dalam salah satu pasal undang-undang

\footnotetext{
${ }^{1}$ Baca Tujuan pembangunan nasional dala pancasila dan Undang-undang Dasar 1945, dalam alinea pembukaannya tersurat tentang pengakuan negara untuk memajukan kesejahteraan umum

${ }^{2}$ Lihat payung hukum pembentukan bumdes, Zulkarnain Ridlwan, Fiat Justitia Jurnal Ilmu Hukum Volume 7 No. 3 , Sept Des. 2013
} 
Nomor 6 Tahun 2014 tentang desa secara eksplisit diterangkan pada pasal 87 ayat (1) yang menyatakan tentang pendirian BUMDes yang dapat dilakukan oleh desa, pengelolaan dilakukan oleh desa itu sendiri dengan jiwa kekeluargaan dan kegotong royongan. Dari pasal tersebut terlihat bahwa negara berusaha hadir untuk medorong kemajuan dan kemandirian dari desa untuk berpartisipasi ikut serta memajukan daerahnya sendiri. Sehingga nantinya dapat mengurangi tingkat kemiskinan desa.

Dalam kenyataannya BUMDes ini masih bias dalam Konsepsi serta bentuk badan hukumnya. Menurut Ali chaidir dalam bukunya ${ }^{3}$ menyatakan bahwa Badan Hukum yang dibentuk oleh pemerintah adalah badan hukum publik yang disengaaja dibentuk oleh pemerintah untuk kepentingan Negara, contohnya lembaga-lembaga negara, departemen pemerintahan, Daerah Otonom, Badan Usaha milik Negara, Badan Usaha Milik Daerah. Badan Hukum ini dibentuk dengan berdasarkan undang-undang ataupun dengan peraturan pemerintah.

Penjelasan Pasal 87 ayat(1) UU Nomor 6 Tahun 2014 Tentang Pemerintahan Desa disebutkan"BUMDesa menyatakan bahwa secara spesifik tidak dapat disamakan dengan badan hukum seperti perseroan terbatas, CV,atau koperasi. Oleh karena itu, BUMDes merupakan suatu badan usaha bercirikan Desa yang dapat menjalankan beberapa fungsi yang menjalankan dibidang perekonomian yang memiliki perbedaan dengan lembaga perekonomian lainnya. ${ }^{4}$

Secara Filosofis Pembentukan BUMDes ini adalah dikarenakan adanya nilai nilai kehidupan berbangsa dan bernegara yang tumbuh dan berkembang di dalam Kehidupan desa, dimana diharapkan dengan adanya BUMDes dapat menjadi alat penggerak ekonomi Keerakyatan.

Lembaga yang didirikan tidak hanya sebagai alat untuk mencari keuntungan / profit oriented semata namun juga sebagai alat penggerak perekonomian masyarakat dan ikut serta mendorong keikutsertaan masyarakat membangun desanya. Secara sosiologis badan ini diharapkan dapat menggerakkan pemerintah desa untuk lebih giat membangun daerahnya dengan segala aturan adat setempat dan kearifan local yang dimiliki yang berbeda ditiap desa.

\section{HASIL DAN PEMBAHASAN}

\section{Konsepsi dan Bentuk BUMDes di Provinsi Jambi}

Pola pembangunan dipedesaan selama ini dilakukan secara sentralistik, desa hanya menunggu bantuan dari pusat dalam hal pembiayaan pembangunan desa dan kesan yang ditimbulkan adalah desa merupakan obyek pembangun. Ketika desa itu menjadi obyek maka ia cenderung akan pasif, diam menunggu gerakan dari pemerintah pusat, mengucurkan dana untuk pembangunan dan dialokasikan dalam APBN.

Seringkali bantuan tersebut tidak sesuai dengan kebutuhan yang benar benar dibutuhkan desa dan konsep pembangunan melalui bantuan tidak memberdayakan, sebaliknya malah menciptakan kultur ketergantungan atau kultur meminta dari masyarakat pedesaan.

Walaupun tujuan pemberian bantuan dana ini membantu mengatasi permasalahan perekonomian desa, pemberdayaan ekonomi masyarakat,dan mendukung pembangunan didesa. Banyak penyelewengan yang dilakukan baik disengaja ataupun karena ketidaktahuan perangkat desa untuk menggunakan dana bantuan tersebut ${ }^{5}$.

Ide dasar dibentuknya badan ini diawali dari adanya amanah undang-undang pemerintah desa ini terkait dengan tata kelola terhadap asset yang merupakan milik desa yang nantinya diupayakan sebagai sarana bagaimana meningkatkan pendapatan dari masyarakat setempat.

Sebagai suatu pendekatan relative baru dalam bidang usaha dalam rangka peningkatan ekonomi desa yang mendasarkan kebutuhan dan potensi desa. Partisipasi masyarakat desa sangat dibutuhkan sepenuhnya dalam proses pengelolaan BUMDes. Dalam hal ini sebagai lembaga perekonomian didesa BUMDes akan menerima semua kegiatan ekonomi sebagai wujud lembaga atau badan usaha yang akan dikelola secara serius, dan selalu mendasarkan pada kemampuan sumber daya asli desa dengan alas an agar masyarakat lebih menghasilkan dan berdaya guna. ${ }^{6}$

Jika merujuk pada konsep antara BUMDes dengan badan Hukum usaha lainnya yang kita kenal maka akan terlihat perbedaan yang bisa dilihat ${ }^{7}$ kepemilikan, Status badan Hukum, pendiri, pertanggungjawabannya, sumber dana dan asset.

Sebelum adanya konsep BUMDes yang sesuai diamanatkan UU Desa, di kabupaten muaro bungo, salah satu Kabupaten di Provinsi Jambi telah mengenal Konsep badan usaha seperti BUMDes yang dikenal dengan istilah

3 Lihat Ali Chidir, Badan Hukum Penerbit Alumni, 1987

4 Permendes PDTT Nomer 4 Tahun 2015 Tentang Pendirian, Pengurusan, dan Pengelolaan dan Pembubaran Badan Usaha Milik Desa

${ }^{5}$ https://kompaspedia.kompas.id/baca/paparan-topik/kasus-kasus-penyelewengan-dana-desa-sejak-2015

${ }^{6}$ Reza M. Zulkarnaen sebagaimana dalam Alda Rifada Rizqi, jurnal AJUDIKASI : Jurnal Ilmu Hukum, Volume 3 Nomor 1, Juni 2019. Hlm 27-40 Eksistensi Badan Usaha Milik Desa (BUMDES) dalam Upaya Mewujudkan Negara Hukum Kesejahteraan 27 Eksistensi Badan Usaha Milik Desa (BUMDES) dalam Upaya Mewujudkan Negara Hukum Kesejahteraan

${ }^{7}$ Baca Eksistensi Badan Usaha Milik Desa (BUMDes) Dalam Pengembangan Usaha dan Ekonomi DEsa Yang berdaya Saing di Era Masyarakat Ekonomi ASEAN, Jurnal UNJAZ Bengkulu 
BUMDus. Konsep dari BUMDus ini adalah lembaga yang dipergunakan sebagai sarana untuk meningkatkan partisipasi masyarakat dalam pembangunan yang diakomodir dalam suatu Perda tersebut yaitu nomor 19 Tahun 2012 Tentang Pedoman Pembentukan Badan Usaha Milik Dusun (BUMDus).

Konsep tentang Bumdes sudah ada diMuaro Bungo jauh sebelum UU Desa lahir walaupun dengan nama sedikit berbeda. Dasar pertimbangan adanya Bumdus ini adalah salah satu upaya peningkatan ekonomi dusun yang kuat serta mandiri.

\section{Peranan BUMDes dalam Perekonomian Dalam Perwujudan Kesejahteraan Masyarakat Desa}

Tugas terpenting pemerintah terhadap warga negara sebagaimana diamanatkan konstitusi, yang disebutkan secara gamblang yaitu untuk memajukan kesejahteraan umum. Untuk menjabarkan apa itu sejahtera maka dikelurkan UU Nomor 11 Tahun 2009 Tentang Kesejahteraan Sosial.

Sejahtera menurut Pasal 1 ayat (1) Undang-undang kesejahteraan sosial dikatakan sebagai keadaan terpenuhinya kebutuhan material, rohani dan sosial warga negara hidup layak serta dapat mengembangkan fungsi sosialnya. Konsep sejahtera itu masih sangat abstrak, maka dari itu Adi dalam bukunya menyatakan tentang parameter secara umum bagaimana pengukuran tingkat kesejahateraan masyarakat dengan melihat tingkat ekonomi, perumahan, pendidikan, kesehatan, lingkungan hidup, spirituak, rekreasional, serta adanya jaminan sosial ${ }^{8}$.

Jalannya pembangunan desa akan sangat membutuhkan dukungan akan kebijakan dan kewenangan yang secara penuh diberikan dari pemerintah pusat. Tidak hanya semata mata bantuan sejumlah dana pembangunan semata, namun juga kepercayaan yang diberikan untuk mengelola sumber daya alam yang ada didesa untuk dikelola dan diolah dengan mengikut sertakan masyarakat. Keinginan ini diakomodir dalam Undang-undang Desa, pendirian suatu Badan Usaha yang akan mengapresiasi usaha dibidang ekonomi dalam rangka peningkatan pendapatan desa yang mengikut sertakan masyarakat, sehingga masyarakat tidak hanya sebagai obyek/ penonton saja dalam proses pembangunan namun juga ikut serta untuk mengawasi jalannya usaha dari BUMDes.

Kebijaksanaan pemanfaatan sumber hayati seperti yang telah dijelaskan pada Pasal 33 ayat (3) dalam konstitusi, dikatakan bahwa penguasaan atas Kekayaan Hayati baik yang ada diatas maupun dibawah bumi dikuasai oleh negara tetapi penguasaan ini juga memperhatikan apakah nantinya membawa kesejahteraan dan kemanfaatan bagi masyarakat. ${ }^{9}$

Sebagaimana amanat konstitusi maka diperlukan usaha yang dilakukan secara tersistematis sebagai cara pemberdayaan dan memandirikan masyarakat desa. Dengan didirikan dan dikembangkannya Badan usaha ini desa maka akan berdampak pada penambahan tingkat pendapatan masyarakat itu sendiri.

Upaya peningkatan Pendapatan Asli Desa dengan jalan pendirian BUMDes dan membuat kegiatan dan model kegiatan dalam membangun dengan mengikutsertakan partisipasi dari masyarakat lokal, dan pencapaian dari mengikutsertakan penduduk setempat ini adalah akan menekan tingkat ketergantungan pendanaan pembangunan menjadikan rule model bagi terbentuknya kegiatan membangun yang diprakarsai dan inisiatif desa.

Pemberdayaan dengan orientasi kemandirian akan mendatangkan dana pembangunan yang berasal dari pendapatan desa, serta akan ada peningkatan kualitas hidup masyarakat dan meningkatkan kemampuan dalam menggali potensi yang dimiliki desa, merencanakan pembangunan dengan melihat kebutuhan apa yang dibutuhkan desa dan tujuan akhir adalah desa dapat keluar dari tingkat kemiskinan akibat ketertinggalan dalam membangun karena ketidak adanya dana yang cukup memadai untuk pembangunan. ${ }^{10}$

Kegiatan memberdayakan perekonomian pada masyarakat pedesaan terutama di Provinsi Jambi terus berkembang dengan bermunculan unit-unit usaha baru . Kehadiran Badan Usaha Milik Desa jika dari aspek ekonomi diharapkan menjadi lembaga penting dalam proses pembangunan desa, walaupun masih terdapat beberapa titik kelemahan yang harus ditingkatkan terutama secara kelembagaan perlu peningkatan kerjasama antar pengelolaan badan usaha, koordinasi diantara unit usaha, serta rencana usaha yang akan dicapai harus jelas apa yang menjadi sasaran yang disesuaikan dengan potensi desa masing masing. Dan dibeberapa wilayah kabupaten di Provinsi Jambi masih ada kendala . Upaya secara sistematis serta berkelanjutan akan mendorong BUMDes untuk pengelolaan asset serta pengembangan jaringan perekonomian terutama membuat pangsa pasar dari produk desa sehingga akan ada peningkatan daya saing perekonomian desa.

${ }^{8}$ Adi, I R 2013, Kesejahteraan Sosial ( Pekerjaan Sosial, Pembangunan Sosial, dan Kajian Pembangunan) PT Raja Grafindo Persada

${ }^{9}$ Muchsan sebagaimana dikutip dalam Agus Surono, jurnal Rechsvinding, volume 6 Nomor 3 Desember 2017, Peranan Hukum Dalam Pengelolaan Sumber Daya Alam Skala Desa Oleh Badan Usaha Milik Desa ( BUMDes) Dalam Meningkatkan Kesejahteraan Masyarakat Desa

10 Laporan penelitian banglitbangda, Model Pengembangan BUMDes Guna Meningkatkan Inovasi Kemandirian Masyarakat Di Provinsi Jambi, M.Rialdi Syaputra, ASnelly Daulay, NatResEco, Elwamendri 
Harapan besar terhadap badan usaha bisa menstimulus serta dapat mendorong ekonomi desa sehingga asset perekonomian yang dimiliki desa sepenuhnya dikelola sendiri dengan tanpa menghilangkan semangat kebersamaan yang dimiliki masyarakat sebagai kearifan lokal. Dalam tahapan ini badan usaha maju dan bergerak bersama sama masyarakat untuk meningkatkan pendapatan asli daerah, serta mengurangi kegiatan perekonomian yang bersifat negative seperti kegiatan rentenir ${ }^{11}$

Dengan memutus praktek rentenir maka kesejahteraan masyarakat akan lebih terjamin. Harapan dari pelaksanaan BUMDes juga untuk memutuk praktek tengkulak namun terkadang upaya pemutusan praktek tengkulak berhambat karena terkadang justru yang melakukan praktek tersebut justru perangkat desa itu sendiri. Dengan pemutusan mata rantai kegiatan tengkulak maka secara tidak langsung akan membawa peningkatan sektor perekonomian, dan jangka panjang dapat menekan jumlah kemiskinan. Namun akan berbanding terbalik dan menjadi pr yang susah di selesaikan manakala yang melakukan kegiatan praktek itu adalah keluarga dari aparat pemerintahan desa atau penguasa. Dan akan menjadi hambatan tersendiri dalam pelaksanaan kegiatan BUMDes.

\section{Tantangan Dan Hambatan Dalam Pengelolaan BUMDes}

Tujuan didirikannya BUMDes sebagaimana diatur dalam Pasal 3 Permendesa, antara lain meningkatkan perekonomian Desa, mengoptimalkan aset Desa agar bermanfaat untuk kesejahteraan, sehingga tercipta sebuah kesempatan dalam rangka peningkatan pendapatan masyarakat desa. ${ }^{12}$ Namun dalam kenyataan dilapangan ada hambatan dan dinamika dalam pelaksanaan sebuah program merupakan suatu yang tidak dapat dielakkan demikian juga dalam pelaksaan BUMDes di desa-desa yang menjadi objek penelitian ini dimana BUMDes-nya juga mengalami beberapa kendala dalam operasionalnya.

Setiap Kabupaten di Provinsi Jambi memiliki permasalahan yang beragam dalam pengelolaan BUMDes. Sesuai dengan sampel area penelitian yaitu Kabupaten Muaro Bungo, Kabupaten Bangko serta Kabupaten Tanjung Jabung Barat.

\section{Kabupaten Muaro Bungo}

Permasalahan hukum yang timbul dalam pengelolaan BUMDus yaitu adalah:

1. Managemen pemerintahan desa.

Pengelolaan desa terkadang terkendala dengan kualitas SDM yang dimiliki yang tidak seragam sehingga menjadi permasalahan baru terlebih bagi kepala desa secara ex officio merupakan penasehat BUMDes, yang memiliki kewajiban yang terikat secara langsung terhadap pelaksanaan dan pengelolaan BUMDes.

2. Permasalahan yang dipicu oleh munculnya pertentangan diantara Pemerintah dan BUMDus terutama ketika ada pergantian Rio. Keadaan ini muncul ketika arah politik yang berkepentingan berbeda. Yang secara tidak langsung akan mengganggu pengelolaan BUMDus itu sendiri bahkan bisa terbengkalai pengelolaannya.

3. Sumber Daya alam yang berbeda beda tiap Dusun sehingga penentuan bidang usaha jadi masalah tersendiri.

Tidak semua Dusun memahami apa yang menjadi andalan komoditi yang bisa diandalkan yang bisa dijadikan bidang usaha bagi BUMDus

4. SDM pengurus yang berbeda beda.

Kualitas yang diharapkan dari setiap pengurus BUMDus seharusnya sama dalam cara pandang pengelolaan, namun terkadang ini yang jadi permasalahan dimana setiap anggota pengurus tidak memiliki latar belakang, pengetahuan yang cukup dalam mengelola sebuah badan usaha.

5. Pengawasan yang kurang yang disebabkan minimnya SDM.

Pasal 15 ayat 1 Permendesa No 4 Tahun 2015 secara tegas menjelaskan siapa yang bisa menjadi pengawas yaitu orang yang berkepentingan yang merupakan wakil masyarakat. Dalam hal ini terkadang persyaratan menjadi pengawas tidak dapat terpenuhi sebagaimana ketentuan seperti jiwa wira usaha yang harus dimiliki pengawas, ataupun syarat pendidikan yang mensyaratkan minimal SLTP.

6. Penyertaan Modal dengan pihak ke 3 atau perorangan.

Pihak ke 3 menginginkan ada rasa terlindungi bahwa modal yang disetor ke badan usaha akan aman.

7. Kondisi pandemic covid-19 yang menyebabkan tidak maksimal dalam memperoleh omset bahkan ada beberapa badan usaha yang terpengaruh seperti yang bergerak dibidang Peternakan dan pariwisata.

8. Bentuk Badan usaha yang senantiasa dipertanyakan oleh pihak ke3 ketika mereka akan melakukan kerjasama. Yang menginginkan untuk berbadan hukum layaknya badan hukum yang dikenal dalam dunia usaha.

\footnotetext{
${ }^{11}$ Nurcholis, Hanif Pertumbuhan dan Penyelenggaraan Pemerintah Desa. (2011) Jakarta, Erlangga.

${ }^{12}$ M Muslih, pelaksanaan Program Badan Usaha Milik Desa (BUMDes) di Kecamatan Jambi Luar Kota Kabupaten Muaro Jambi, jurnal Wajah Hukum, volume 4 \{2), Oktober 2020, 500-505
} 


\section{Kabupaten Bangko}

Permasalahan Hukum yang senantiasa menjadi hambatan dalam pengelolaan BUMdes yaitu :

1. Masalah Sinergisitas antara Pemerintah Desa dan BPD dan pengurus BUMdes. Pengelolaan BUMDes itu memerlukan hubungan yang solid antara penasehat, pengelola operasional serta pengawas. Semua pihak memiliki peran penting yang akan mendukung pelaksanaan BUMDes.

2. Badan Hukum BumDes ketika BUMdes akan Bekerjasama dengan pihak ketiga yang menginginkan unit usahanya berbadan hukum yang terdaftar dalam akta notaris. Bukan semata mata berdasarkan peraturan desa semata.

3. Dukungan masyarakat desa yang sangat minim. Terutama bagi masyarakat yang memiliki pemahaman tentang BUMDes rendah. Justru desa dengan potensi bagus, BUMdesnya seringkali tidak berjalan maksimal, namun justru desa yang memiliki potensi yang minim justru masyarakatnya termotivasi untuk maju untuk membangun desa mereka.

\section{Kabupaten Tanjung Jabung Barat}

Penelitian di Dataran Kempas menunjukkan beberapa hasil dilapangan bahwa ada permasalahan hukum yang senantiasa menjadi hambatan dalam pengelolaan BUMdes yaitu :

1. Masalah Sumber Daya Manusia dalam memanage BUMDes.

Pengelolaan badan usaha ini seringkali terkendala dengan Sumber Daya Manusia yang ada, baik tingkat pendidikan maupun pemahaman kewirausahaan bagaimana mengelola sebuah badan usaha.

2. Perbedaan visi dan pemahaman tentang BUMDes.

Cara memahami aturan juga berimbas pada bagaimana mengelola BUMdes, ini tentunya menjadi permasalahan tersendiri dalam menjalankan badan usaha yang ada.

3. Adanya keinginan BUMDes untuk berbadan hukum.

Keinginan ini timbul seiring dengan banyaknya pihak ke 3 yang menginginkan kejelasan tentang status badan usaha ini, ketika akan bekerjasama.

\section{SIMPULAN}

Konsep BUMDes di Provinsi Jambi dipahami berbeda beda karena kendala pemahaman tentang BUMDes itu sendiri. Sebagai lembaga yang dibentuk untuk mendorong kesejahteraan masyarakat BUMdes sangat potensial dapat mensejahterakan masyarakat desa dan menurunkan angka kemiskinan. Namun dengan adanya beberapa kendala atau hambatan dalam pelaksanaan BUMDes terutama selama pandemic covid 19 beberapa BUMDes ada yang terpengatuh oleh keadaan tersebut.

\section{DAFTAR PUSTAKA}

Buku

Adi, I R 2013, Kesejahteraan Sosial (Pekerjaan Sosial, Pembangunan Sosial, dan kajian Pembangunan) PT Raja Grafindo Persada

Ali Chidir, Badan Hukum Penerbit Alumni, 1987

Nurcholis, Hanif Pertumbuhan dan Penyelenggaraan Pemeritahan Desa. (2011) Jakarta, Erlangga.

\section{Jurnal}

Abdul Aziz Zulhakim, Eksistensi Badan Usaha Milik Desa (BUMDes) Dalam Pengembangan Usaha dan Ekonomi DEsa Yang berdaya Saing di Era Masyarakat Ekonomi ASEAN, Jurnal UNJAZ Bengkulu

Agus Surono, jurnal Rechsvinding, volume 6 Nomor 3 Desember 2017, Peranan Hukum Dalam Pengelolaan Sumber Daya Alam Skala Desa Oleh Badan Usaha Milik Desa ( BUMDes) Dalam Meningkatkan Kesejahteraan Masyarakat Desa

M Muslih, pelaksanaan Program Badan Usaha Milik Desa (BUMDes) di Kecamatan Jambi Luar Kota Kabupaten Muaro Jambi, jurnal Wajah Hukum, volume 4 \{2), Oktober 2020, 500-505

Zulkarnain Ridlwan, Payung Hukum Pembentukan Bumdes, Fiat Justitia Jurnal Ilmu Hukum Volume 7 No. 3, Sept Des. 2013

Reza M. Zulkarnaen, Pengembangan Potensi Ekonomi Desa Melalui Badan Usaha Milik Desa (BUMDES) Pondok Salam Kabupaten Purwakarta, Jurnal Dharmakarya, Volume 5, No. 1, Mei 2016. Dalam jurnal

\section{Undang-undang}

Undang-undang Nomor 6 Tahun 2014 Tentang Desa

Permendes PDTT Nomer 4 Tahun 2015 Tentang Pendirian, Pengurusan, dan Pengelolaan dan Pembubaran Badan Usaha Milik Desa 
Lili Naili Hidayah, Muskibah dan Ageng Triganda, Konsepsi dan Bentuk BUMDes dalam Peningkatan Kesejahteraan Masyarakat di Provinsi Jambi

\section{Internet}

https://kompaspedia.kompas.id/baca/paparan-topik/kasus-kasus-penyelewengan-dana-desa-sejak-2015 